\title{
Scientific Approach to Improve the Critical Thinking Skills
}

\author{
$1^{\text {st }}$ Karlina Wong Lieung* \\ Departmen of Pre-School and \\ Elementary School Education \\ Universitas Musamus \\ Merauke, Indonesia \\ lieung@unmus.ac.id
}

\author{
$2^{\text {st }}$ Dewi Puji Rahayu \\ Departmen of Pre-School and \\ Elementary School Education \\ Universitas Musamus \\ Merauke, Indonesia \\ rahayu@unmus.ac.id
}

\author{
$3^{\text {st }}$ Fredy \\ Departmen of Pre-School and \\ Elementary School Education \\ Universitas Musamus \\ Merauke, Indonesia \\ fredy_pgsd@unmus.ac.id
}

\begin{abstract}
The purpose of this research is to improve critical thinking skills on fourth grade elementary school students on thematic integrated through scientific approach. The implementation of this research conducted by class action research method which has three cycles. The subject of this research is the students of $\mathrm{IV}-\mathrm{A}$ class in Laboratorium elementary school UPI Cibiru which has 22 students in class (10 girls and 12 boys). Data collection technique through an interview, observation, field report and documentation. Data analyzing is use interactive analysis. The procedure was colaborative classroom-based research. The result of research is shows critical thinking students on the first cycle $43,6 \%$ with the average score 39,24. Second cycle shows at least $60,97 \%$ with average score 54,88 . And the third cycle achieve $81,48 \%$ with average score at 73,33 . The conclusion is, critical thinking skills students had increased after carried out class action research.
\end{abstract}

\section{Keywords — scientific approach, critical thinking skills}

\section{INTRODUCTION}

Humans are perfect beings who are gifted with reason. Intellect can grow well when getting the right education. Education can be in the form of formal or non-formal education. Formal education can be obtained through formal education institutions, namely schools. Schools are institutions that provide educational services for students to become ideal human beings who are aspired through a series of learning processes based on the curriculum.

Curriculum is the implementing guidelines of learning in school. There are several curriculum ever imposed in Indonesia, such as 1947, 1952, 1964, 1968, 1975, 1984, 1994, 2004, 2006 curriculums, and the newest are 2013's Curriculum. The curriculum is always changing as the development of the times. One of the new is the curriculum that was being piloted in 2013. The striking differences between the curriculum in 2013 with Kurikulum Tingkat Satuan Pendidikan (KTSP) is the implementation of integrated thematic learning for grade I-VI Elementary School. Curriculum 2013 offers convenience for teachers and students in learning with books formulation teacher and student books.

The 2013 curriculum, implements integrated learning based on the combination of integrated learning webbed models and integrated models. Model webbed according to
Robin Fogarty [1] implement a thematic approach where the theme is a binder few topics or skills better than one subject or several subjects. This model is most popularly used. In addition, learning to apply the 2013 curriculum also integrated models. This model according to Robin Fogarty [1] combines a field of study, subjects or disciplines as a whole without sight parts with one another. This is done to optimize time on topics that overlap in different subjects. This model was applied in 2013. The curriculum combines integrated thematic learning webbed models that use the theme as a binder, and integrated models that combine subjects in the theme subtly. This means look no further various subjects such as the old curriculum but a theme that will develop the cognitive, affective and psychomotor once.

Observations made in Laboratorium elementary school UPI campus Cibiru. The results show that the students started to realize the task of learning and can complete the tasks of learning. It is seen from the attitude of the students when the course. When the teacher explained, most of the students listening to what the teacher said. Based on the observation, teachers are more focused on workmanship of the student's book and the material are less developed because the students are working the tasks of their book. Several students attitude are less disciplined. Students are still less concentrated and often talking during the lesson progresses.

This is not in accordance with the objectives of the education era in the year 2000. In the 2000 era, educational goals included critical thinking skills, problem solving and communication [2]. These skills are interrelated and are equally focused in contemporary education. [3] critical thinking ability is defined as the ability of a person to be able to think reflective and reasonable, in deciding what is believed or what must be done.

A critical thinker is able to analyze all phenomena that occur and make good decisions in every problem faced. This shows a positive relationship between critical thinking skills and problem solving skills. [4] Illustrated that critical thinking is a process of identification and the process of finding out from several assumptions, having feelings of doubt about the opinions or statements of others, trying to find new alternatives and arguing by giving clear reasons. This definition is closely related to the definition of problem solving skills. However, not all humans are able to use 
critical thinking skills in various situations so that a person's ability to solve problems is often difficult to obtain [5]. Implementation of the 2013 curriculum raises a scientific approach as a major approach in learning activities. Providing science provides students with a contextual learning experience [6]. Moreover, it can improve students' science process skills [7]. The scientific approach is an approach that requires students to exercise as a science specialist. The series of activities in question include: 1 . formulating the problem; 2 . propose a hypothesis; 3 . collecting data; 4. processing and analyzing data, and; 5. make a conclusion [8]. Classroom learning can be conditioned to fulfill these steps simply to be easily followed by elementary school students. The characteristics of learning with scientific methods [9] are: 1. student-centered; 2 . involve the skills of the process of science in constructing concepts, laws or principles; 3 . involves potential cognitive processes in stimulating the development of the intellect, especially the students' high-order thinking skills; and 4. can develop student character.

Regardless of the discipline problem related to the children age, there is something very fundamental that researchers initiate to improve in teaching and learning activities. Students are capable enough to accomplish the task of learning on the text book. However, if given the task of studying understanding many students are not able to finish.

Students are able to answer questions with the kind of questions what, when, where, who. But for the kinds of questions that seek answers to further deepen the understanding as to why and how the student cannot answer completely. Students answer questions of this type are often merely a text book. Based on these observations, researchers believe that the students' critical thinking skills must be improved.

According to Edward Glaser [10] critical thinking someone must have some capabilities such as:

(a) recognize the problem; (b) to find ways that can be used to address those problems; (c) collect and collate the necessary information; (d) recognize the assumptions and values that are not declared; (e) understand and use language that is appropriate, clear and distinctive; (f) analyze the data; (g) assessing the facts and evaluate the claims; (h) recognize the logical ties between the problems; (i) draw conclusions and commonalities required; $(j)$ examine the commonalities and conclusions that someone take; $(\mathrm{k})$ reconstruct patterns of a person's beliefs based on wider experience; and (l) to make a proper assessment of things and certain qualities in everyday life.

In order to achieve that the indicators, researchers tried to use a scientific approach. Expectations of researchers, students desire to always move can be channeled through a variety of activities that support learning. Students are given the trust to be responsible and actively carry out a series of activities that have been designed teachers to be able to resolve the issue. The activity of which students are given the opportunity to make observations or careful observation to identify everything from the object being observed. After the students were given the opportunity to express questions, express opinions and conduct experiments. Students are also allowed to brainstorm with her friend to share knowledge and insights they have earned.
Formulation of indicators of critical thinking used in CAR this time includes three main points. Among other things to ask, listen actively, and to provide and appreciates the contribution. Learning steps that will researchers use a five-step application $M$ such as observe (Mengamati), to question (Menanya), to reason (Menalar), to try (Mencoba) and make networking (Membuat jejaring). If these five steps are carried out properly, the students' ability to understand the material, the better.

Students will be challenged to continue to actively asked questions and brainstorm of all the objects that the students observe. However, it should also be made of students with discipline, as a result of the practice of the value of the character. Therefore, CAR this time also intersect with the character education of primary school. Especially on points of discipline which, according Kemdiknas [8] that the disciplinary action showed orderly behavior and comply with various rules and regulations. However, the subject of elementary school students, classroom management or management class is also a very important thing.

Class management approach authoritarian, permissive, cookbooks, socio-emotional climate. Authoritarian approach which is used among other things as follows [11].

1. Establish and enforce rules.

2. Gives the command, direction and message.

3. Using a reprimand.

4. Using the control approach.

5. Using the separation and exclusion.

Researchers combine the permissive approach and socioemotional climate. The goal is that students feel closer to the teacher, and feel comfortable in learning. The applicable rules can be implemented with full awareness and responsibility. Elementary school age students, especially elementary Lab UPI has the potential for very high intelligence, but tend to be more difficult to manage. Thus the management or good classroom management will be very useful for the sake of implementation of conducive learning process.

Based on the problems that arise, it is necessary to conduct classroom action research by applying the scientific approach to improve critical thinking skills of elementary school students.

\section{RESEARCH METHODS}

This research is Classroom Action Research (CAR). The CAR method tends to be qualitative and involves in-depth interactions between research subjects, participants and researchers. Interaction is carried out in the form of direct observation, participant observation and in-depth interviews.

Understanding CAR according to Suharsimi Arikunto [12] explains that CAR consists of three words, namely:

Research is defined as the activity of seeing an object by using certain methods and rules or methodologies to find accurate data about things that can improve the quality of observed objects; the planned action is a movement with a specific purpose; and classroom is a place where there are a number of students at the same time get similar teaching and from the same teacher. 
So this PTK can be done by education practitioners (teachers) and other people who have attention to the world of education and want to improve the quality of education and/or learning.

The research design used was John Elliot's design, with the CAR subject consisting of 22 students from SD Lab UPI Kampus Cibiru IV-A class. In general, the stages or procedures of classroom action research begin with: problem identification, field examination, action plan preparation, observation and reflection.

The instruments used were in the form of tests and nontests. Test the form of an evaluation sheet to measure learning outcomes. Non-tests in the form of observation sheets, interviews, field notes and photographs as documentation to assess students' activities and critical thinking skills.

Data analysis techniques through qualitative and quantitative data analysis. Qualitative data is obtained from teacher assessment using instruments in the form of observation sheets, interview sheets, field notes and documentation. The assessment of critical thinking and the character raised by the students in this study were given a scale of values on their observations by first preparing rubric scoring. The value scale used is to give the numbers 1,2 , or 3 . So the highest score is 3 . To calculate the average score converted into standard 100 can use the formula:

$$
\text { Average }=\frac{\text { Total score }}{\text { Number of aspects }} \times 100
$$

Qualitative data is obtained from the results of tests in the form of evaluations conducted to find out how far the student's learning outcomes are improved after learning with the scientific approach. Quantitative data analysis is carried out with the following steps.

Give a score on students' answers to the technique that will be attached to the lesson plan; calculate the average value obtained by students in a group (class) through a formula adapted from Nana Sudjana [13].

$$
R=\frac{\sum x}{\sum n}
$$

Description: $\mathrm{R}=$ Average value of students

$$
\begin{aligned}
& \sum x=\text { number of all students scores } \\
& \sum n=\text { number of students }
\end{aligned}
$$

Calculate the percentage of learning completeness of students who graduate in class IV with the formula:

$$
P=\frac{\sum p}{\sum n} x 100 \%
$$

Description: $\mathrm{P}=$ percentage of students who graduate

$$
\sum p=\text { number of students who graduate }
$$

$\sum n=$ number of all students

If the student learning outcomes of all students from the evaluation and assessment of critical thinking have passed $75 \%$. This means that $75 \%$ of students have values above the Minimum Completion Criteria (KKM) and indicators of criteria for achievement of critical thinking skills, so the research is considered successful.

\section{RESUlt AND Discussion}

The implementation phase of the study conducted by researchers consists of three cycles, each cycle consisting of three acts. Results of this study illustrate how the activity, critical thinking skills and student learning outcomes after the action. So as to prove successful or not use a scientific approach to learning integrated thematic curriculum 2013.

The first cycle results shows that the students are very difficult conditioned in learning activities and passive when conducting debriefing. When question and answer activities, only three students actively participated. This has implications for learning outcomes and students' critical thinking skills are very low. The average value of the evaluation of student achievement KKM reached 62.12 with $33.33 \%$. While critical thinking skills reached $43.6 \%$ with an average value of 39.24.

The second cycle shows that students were beginning to actively question and answer with the teacher even though some student still difficult learning conducive. The critical thinking skill of students has increased compared to previous cycles. This is because the more active teachers motivate students in learning activities, especially during the question and answer. Students are more conditioned than the previous cycle. It has implications for the learning outcomes of students in the second cycle which has increased better than the first cycle. The average value is based on an evaluation reaches Cycle two reach 71.74 by $60.61 \%$ KKM achievement. Critical thinking skills increased to $60.97 \%$ with an average value of 54.88 .

The third cycle suggests that students' motivation has increased more sharply than the previous cycle. Students began to show awareness in the following activities of observation, question and answer, and experiment. Students learn more conditioned and conducive. Students are very orderly and very active in the question and answer, and do not hesitate anymore. Students learning outcomes are achieve 81.21 with $80.30 \%$. Critical thinking skills reached $81.48 \%$ with a value of 73.33 .

The increase results from each cycle and can be shows in the following graph.

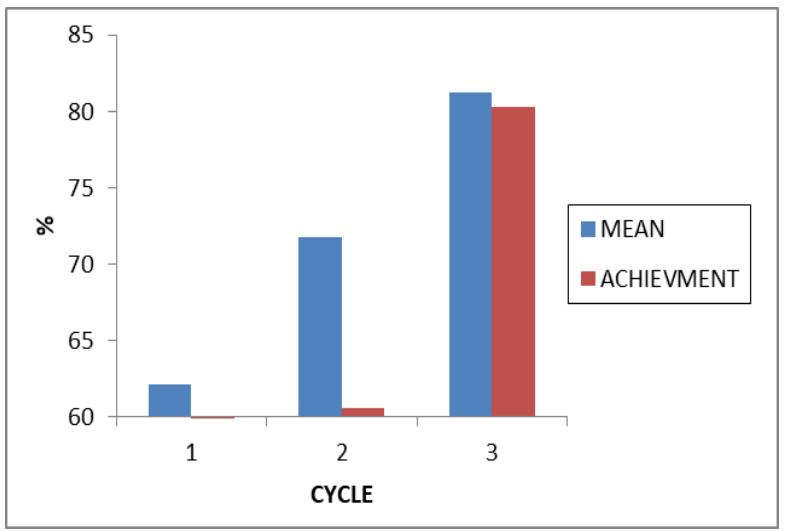

Fig 1. Average Value Evaluation Students Each Cycle 


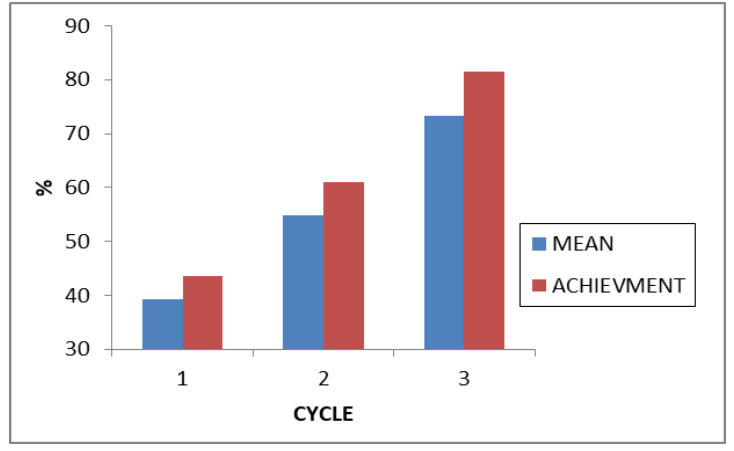

Fig 2. Average Value Critical Thinking Ability Students per cycle

The application of the scientific approach in learning integrated 2013 thematic curriculum has increased. This is in accordance with previous research conducted by Erni Kusmini. This study uses an integrated learning model with a scientific based approach to increase cooperative learning. Learning that is done is learning science combined with several other subjects. The results, student scores increase in each cycle, as well as with the CAR of this team.

\section{CONCLUSION}

Classroom action research conducted on the subject of elementary school students UPI Campus Laboratory Cibiru, Kab. Bandung has done. Based on these results the researchers draw conclusions about several things including the following.

1. The behavior of fourth grade students learning Laboratory assessed through observation sheet showed improved results from action to action. Starting from discipline to student learning activities showed increased yields to a better direction of each meeting. This indicates that the teachers have been able to manage a class well. Students have to have more motivation in participating in learning. So that students can carry out the activity of observing, questioning, experimentation and create networking or collaboration with consciousness itself without having directed the teachers continuously. It is seen from the behavior of students in the observation sheet that is attached to the end of the report.

2. critical thinking skills of students after participating in integrated thematic learning by applying the scientific approach has increased significantly. It can be seen in the results of assessment of critical thinking skills in chapter IV.

3. Student learning outcomes are assessed based on the final test in the form of an evaluation sheet given to every end of the learning increased. According to data obtained at the end of the lesson, there is only one student who did not reach the KKM. While at the beginning of learning, only four students who achieve KKM.

Based CAR has been done, the researchers make recommendations on some of the following.

1. The behavior of the students learn better when teachers can manage the class and interact with students.
2. It can help students in a variety of activities in a scientific based approach. If these steps can be carried out with good learning, critical thinking skills can be maintained and even improved. Teachers can provide additional indicators to assess students' critical thinking skills.

3. The results of student learning can be maintained and improved if steps one and two can be done well, the teacher can use a variety of teaching methods and classroom management [14].

\section{ACKNOWLEDGMENT}

This work was supported and facilitied by Universitas Musamus.

\section{REFERENCES}

[1] A. Heriawan and D. A. Senjaya, Metodologi Pembelajaran: Kajian Teoretis Praktis. Banten: LP3G, 2012.

[2] T. D. Erwin and E. Al., The NPEC Sourcebook on Assessment, Volume 1: Definitions and Assessment Methods for Critical Thinking, Problem Solving, and Writing. Washington DC: National Postsecondary Education Cooperative (NPEC), 2000.

[3] R. H. Ennis, "A Logical Basis for Measuring Critical Thinking Skills," 43, 1985

[4] S. D. Brookfield, Developing Critical Thinkers : Challenging Adult to Explore Alternative Ways of Thinking and Acting. San Francisco: Jossey-Bass Publishers. Oxford, 1991.

[5] K. W. Lieung, D. P. Rahayu, Fredy, and A. Sulili, "The influence of scientific approach on environmental problem solving skills in elementary school students," IOP Conf. Ser. Earth Environ. Sci. vol. 343, no. 1, 2019, doi: 10.1088/1755-1315/343/1/012173.

[6] D. P. Rahayu, K. W. Lieung, and Fredy, "The use of reading material based contextual approach to improve environmental concern attitude of elementary school students," IOP Conf. Ser. Earth Environ. Sci., vol. 343, no. 1, 2019, doi: 10.1088/1755$1315 / 343 / 1 / 012225$

[7] Fredy, K. W. Lieung, R. Butarbutar, and A. Duli, "Science process skills in learning environmental pollution using PBL models," IOP Conf. Ser. Earth Environ. Sci., vol. 343, no. 1, 2019, doi: 10.1088/1755-1315/343/1/012179.

[8] Y. Abidin, Pembelajaran Bahasa Berbasis Pendidikan Karakter Bandung: Refika Aditama, 2012.

[9] Daryanto and Darmiatun, Implementasi Pendidikan Karakter di Sekolah. Yogyakarta: Gava Media, 2013.

[10] A. Fisher, Berpikir Kritis: Sebuah Pengantar. Jakarta: Erlangga, 2009

[11] M. Rachman, Manajemen Kelas. Semarang: Kemdikbud, 1999.

[12] E. Komara, Penelitian Tindakan Kelas dan Peningkatan Profesional Guru. Bandung: Refika Aditama, 2012.

[13] W. Deka, "Deka, Warman. (2013). Penerapan pendekatan contectual teaching and learning (CTL) pada pembelajaran matematika materi bangun ruang untuk meningkatkan hasi belajar siswa. [Online]. Tersedia:

repository.upi.edu/1920/6/S_PGSD_0902934_Chapter3.pdf Diakses 1,"Universitas Pendidikan Indonesia, 2013.

[14] E. Kustini, "Penerapan model pembelajaran terpadu dengan pendekatan cooperative learning berbasis saintifik untuk meningktkan hasil belajar IPA di sekolah dasar," Universitas Pendidikan Indonesia, 2013. 